\title{
Teachers' Scaffolding Talk in Bilingual Class
}

\author{
Lulu April Farida ${ }^{1}$ \\ \{lulu.farida@mail.unnes.ac.id\} \\ Universitas Negeri Semarang
}

\begin{abstract}
There are obstacles faced by teachers in learning process of physical education in lower grade of elementary school. One of them deals with textbook. It is important to investigate how physical fitness material in elementary school is taught by using TPSR. The purpose of this study is to reveal and produce physical education product development models by using TPSR. This study employed Brog and Gall's method. The results showed the game experts were $98.43 \%$; expert learning 1 was $92.5 \%$; expert learning 2 was $90 \%$; and expert learning 3 was $95 \%$. Affective aspects were elevated from level 0 and 1 . After playing postal triangle using TPSR approach to level 2 and 3, cognitive and psychomotor aspects were $80 \%$ and $79.50 \%$ respectively. Based on the data of attitude, knowledge, and skill, TPSR is able to stimulate students' characters conveying material and provide literacy through attractive visual media which is easy to understand.
\end{abstract}

Keywords: learning model, physical fitness, TPSR

\section{Introduction}

Under the influence of humanistic and communicative theories, a great emphasis has been placed on learning-centered teaching which makes the learning and experience central to the educational process so that the students are actively engaging in relevant experiences and having opportunities to construct their own understanding. The indicator of a good lesson as stated by Harmer is the student's activities during the teaching learning process, not the performance of the teachers ${ }^{[1]}$. In this case, the teachers have to be able to create an interactive class so that the teaching learning process will go hand in hand and finally the students can understand the lesson well.

In creating an interactive class, the teachers are not suggested to keep explaining something to the students. Teachers, in fact, can use the students' knowledge to construct or build their understanding by asking them some questions, giving them some clues, or providing some variations in their teaching to create the students' understanding and also to train their speaking skill. To that extent, it can be assumed that in order to attain the goal of teaching and learning process, the teachers should provide scaffolds or supports to facilitate learner's development. The scaffolds facilitate the student's ability to build on prior knowledge and internalize new information. An important aspect of scaffolding instruction is that the scaffolds are temporary. As the students' abilities increase, the scaffolding given by the teachers is progressively withdrawn[2].

${ }^{1}$ Harmer. J. How to Teach English. An Introduction to the Practice of English Language Teaching.

${ }^{2}$ Sakhiyya. Z. English Teaching-Learning Stage in the Framework of Curriculum 2004 (An Analysis

Teaching in SMAN 3 Semarang Academic Year 2005/2006 by Using Grounded Theory Approach). 
This process of scaffolding is much like the traditional definition of scaffolding as a temporary support system used until the task is complete and the building stands without support. Supports are provided to the students and then gradually removed so that the students can be self-regulated and independent learners[3]. In mastering the concept, the students actually construct and shape it by themselves. They will interact with their surrounding related to the lesson. The teachers here will provide contemporary supports for the students so that the students will be engaged in the teaching and learning process. When they are engaging in this process, they eventually will interact and construct their own understanding under the guidance of the teacher. When they have mastered the lesson, the teacher will gradually decrease the supports.

The function of the supports given by the teacher will clearly and easily be seen in spoken cycle especially in speaking class since the teachers' supports will eventually be tangible and appear through their talks. The teachers here will provide supports to the students in many ways by interacting with them through scaffolding talks. Thus, these talks are actually created by the teachers to lead the students in creating and mastering the concept by themselves.

The use of scaffolding talks by the teachers in teaching speaking would be a paramount thing to discuss in this study. How the teachers provide scaffolds and supports learners has a great contribution to attain the goal of teaching learning process itself since these scaffolding talks do not only lead the students to be independent learners in mastering and understanding the concept but also train their speaking skill. The social constructivism theory is used as the foundation of the scaffolding talks' implementation in the teaching learning process of this study. In short, this study attempts to: a) describe types of scaffolding talks used by the English teachers in teaching speaking and b) explain the functions of scaffolding talks which are given by the teachers.

\section{Research Methodology}

This study used qualitative and quantitative methodologies and the researcher adopted social constructivism theory approach. The basic reason of taking social constructivism theory into account is because of its position as the fundamental ground of the existence of scaffolding talks. This study involved two English teachers in SMAN 4 Semarang along with the teaching learning process in the classrooms. Data of this study consisted of interview and consecutive.

In this study, the researcher analyzed the data by using processes of Noticing, Collecting and Thinking[4]. The purpose of this model is to show that there is a simple foundation to the complex and rigorous practice of Data Analysis. Meanwhile, to count the numbers of scaffolding talks, the researcher used quantitative methodology. The following diagram portrays the process of data analysis.

\footnotetext{
${ }^{3}$ Limpscomb et al. 2004. Scaffolding.

${ }^{4}$ Seidel, J.V. 1998. Qualitative Data Analysis.
} 


\section{Results and Discussion}

\subsection{The Implementation of Teaching Learning Process in the Classroom}

In this point, teacher A taught narrative text to the students by asking the students to work in group. After working in pairs or in a group she asked the students to come forward in front of the class to retell or to give the report of their work. After making the students work in group, she asked them to provide some pieces of paper. In each group, the students were asked to write the heading for each paper, they were the type of narrative, generic structure, lexicogrammatical features, and process. While explaining the students about the characteristic of narrative text, she trained the students speaking ability as well since in this part she also tried to involve the students in her explanation. After ensuring that each group had their task, she let the students to have a small discussion in each group. She asked one of the students in each group to submit all of the papers. Then, the papers were shaken and finally they were distributed for all of the members of the group. The last phase in her teaching learning process was dealing with the students' performance. She asked each group to provide its representative to give a report related to their discussion.

Teacher B used different way in training the students' speaking ability in the classroom. First, she asked the students to repeat after her. Then, she asked the students to find the synonym of the words in English based on the context of the text.. In this part she helped the students to understand the meaning of each word by providing them some clues related to the intended words. The students tried to guest the meaning of the intended words from the clues given by her. She also asked the students to check all of the listed words in dictionary.

3.2 Teachers' Scaffolding Talks in the Classroom

The researcher observed Teacher A when she was teaching narrative text entitled Nyi Roro Kidul. The teacher's scaffolding talks recorded are as follow:

Table 1. Data Calculation of Teacher A's Scaffolding Talks

\begin{tabular}{cccccc}
\hline Reinforcement & $\begin{array}{c}\text { Basic } \\
\text { Questioning }\end{array}$ & Variability & Explaining & $\begin{array}{c}\text { Introductory } \\
\text { Procedures } \\
\text { and Closure }\end{array}$ & $\begin{array}{c}\text { Advanced } \\
\text { Questioning }\end{array}$ \\
\hline 203 & 74 & 188 & 182 & 54 & 10 \\
$.55 \%$ & $10.41 \%$ & $26.44 \%$ & $25.60 \%$ & $7.59 \%$ & $1.41 \%$ \\
\hline
\end{tabular}

In this study, teacher A used skill of reinforcement generally to catch the students' attention and to generate the students' motivation that later on will shape them into a dynamic learning process so that their ability will be trained as well such as verbal reinforcement, gestural reinforcement, and activity reinformcement. In this study, Teacher A gave several numbers of Basic Questioning. Those three Basic Questions were actually given to the students one by one to lead the students' understanding into the goal of the lesson itself that was they had to talk about Narrative text. In order to give clarity of an instruction, Teacher A in this study did phrasing several times. A good question contends one single task only. Thus, the students will know what is expected by the teacher of them to do. The questions given by Teacher A were actually focus enough such as Who got fantasy? Do you get fantasy?. These focused questions can eventually stimulate the students to contribute in the teaching learning process since the task they should do is clear and quite easy. This treatment is actually given to maintain the students' attention, to invite several students to respond. These treatments are usually given by naming 
the students, or by pointing them. Distributing was done by Teacher A in order to involve as many students as possible directly in the lesson and to ensure that there were no students ignored. In this study Teacher A also provided some general rule questions, questions directed to the whole class, group questions, and also personal questions. Pausing is actually given to give students time to think about the question. In this study. Reacting was done by Teacher A to actually show her enthusiasm and warmth of the pupils' responses or answers to the questions. In this study, Teacher A showed her enthusiasm and warmth by demonstrating the questions and the answers from the students in front of the class. When the students fail to give answers of certain questions, teachers must give response to help them. In this study, the way Teacher A gave response when the students failed to answer certain questions was by rephrasing the question and asked other students to help. In this study, the researcher scrutinized the components of variability in term of variations in the teacher's manner or style, variation in the media and materials of instruction, and interaction variation. The explanation of Teacher A in this study was scrutinized and analyzed by researcher to actually describe the teaching learning process conducted. There are six components of explanation: raising key question, promoting clarity, using example, forming connection, making emphasis, and monitoring feedback. Some introductory procedures and closure used are gaining attention, arousing motivation, structuring, making link, and evaluating. The advanced questions given by Teacher A were only simple advanced questions.

The data of teacher B's scaffolding talks is presented in the following table.

Table 1. Data Calculation of Teacher A's Scaffolding Talks

\begin{tabular}{cccccc}
\hline $\begin{array}{c}\text { Reinforceme } \\
\mathrm{nt}\end{array}$ & $\begin{array}{c}\text { Basic } \\
\text { Questionin } \\
\mathrm{g}\end{array}$ & $\begin{array}{c}\text { Variabilit } \\
\mathrm{y}\end{array}$ & $\begin{array}{c}\text { Explainin } \\
\mathrm{g}\end{array}$ & $\begin{array}{c}\text { Introductory } \\
\text { Procedures } \\
\text { and Closure }\end{array}$ & $\begin{array}{c}\text { Advanced } \\
\text { Questioning }\end{array}$ \\
\hline 311 & 136 & 371 & 394 & 142 & 0 \\
$22.97 \%$ & $10.04 \%$ & $27.40 \%$ & $29.10 \%$ & $10.49 \%$ & $0.00 \%$ \\
\hline
\end{tabular}

In this study, Teacher B used skill of reinforcement generally to catch the students' attention and to generate the students' motivation that later on will shape them into a dynamic learning process so that their ability will be trained as well. In this study the researcher scrutinized and categorized this skill of reinforcement into several components. Verbal reinforcements given by teacher B are such as $O K$, good, Yes the leader. Teacher B was quite rare in giving verbal reinforcement to the students. The gestural reinforcement used by Teacher B in this study referred to the teacher's smiles, nods, or pointing as form of non-verbal responses to pupils' contribution in the teaching learning process. In this study, activity reinforcement occurred when Teacher B used an activity or task that made the students comfortable in learning, as reinforcement for the previous good class work or performance. Teacher B used proximity reinforcements above to show the teacher's attention to the students and to motivate them in learning. In this study, Teacher B gave contact reinforcement to the students in term of touching the students when she asked certain students to read some words provided.

In this study, Teacher B gave several numbers of Basic Questioning for some reasons. The main reason was actually to involve the students in the teaching learning process. As stated by Turney, et. al that the use of Basic Questioning in the classroom has several components: structuring (discover means?), phrasing, clarity, and brevity (upset?). Focusing (what is observe?), re-directing (what else?), distributing, pausing, reacting, prompting, changing the level of cognitive demand. In this study, the researcher scrutinized the components of variability 
in term of variations in the teacher's manner or style, variation in the media and materials of instruction, and interaction variation such as voice variations, focusing, pausing, eye contact, gesturing, movement, variations in the media and material instruction, variations in interaction. The explanation of Teacher B in this study was scrutinized and analyzed by researcher to actually describe the teaching learning process conducted by her such as raising key question, prompting clarity, using example, forming connection, making emphasis, monitoring feedback, and introductory procedures and closure.

Regarding the functions of scaffolding talks,teacher A and B in this study used their talks to engage the students in a teaching learning process by capturing the students' attention. Thus the teaching learning process ran well. In this study, Teacher A and B gave students time to think, plan, investigate and organize information to explore the students' knowledge. The activities were given to explore the students' knowledge were: reading some texts, discussion, and students' performance. Teacher A and B used their talks to explain the lesson to the students. In explaining the lesson, they also involved the students in analyzing the texts. Teacher A and B used scaffolding talks to elaborate their explanation. In fact, elaboration was needed to give a comprehensive and holistic understanding and explanation to the students. In this study, Teacher A and B used their talks to evaluate the students understanding or mastery to the lesson. This evaluation was done by asking the students' some questions related to the lesson.

\section{Conclusions}

Based on the discussion presented above, some conclusions can be drawn. Teachers in this study basically implemented the scaffolding talks to construct the students' understanding or mastery upon the lesson or material given. The implementation of the scaffolding talks applied through six kinds of scaffolding talks, i.e. Reinforcement, Basic Questioning, Variability, Explaining, Introductory Procedures and Closure, Advanced Questioning. Each kind of scaffolding talks has its own function, but all of them have the same main function to construct the students' understanding and mastery upon the lesson. Thus, by implementing the scaffolding talks, teachers can eventually lead the students to be independent learners.

The implementation of the teaching learning process in this study is teacher-centered not teaching centered. This teacher-centered hampers the teacher in scaffolding the students since in teacher-centered the talks in the classroom are monopolized by the teachers. Instead of scaffolding the students in learning or mastering the lesson the teachers keep explaining to the students. Thus, the teachers monopolized the talks in the classroom. 


\section{References}

[1] Harmer. J: How to Teach English. An Introduction to the Practice of English Language Teaching. Malaysia: Longman (2001).

[2] Sakhiyya. Z. English Teaching-Learning Stage in the Framework of Curriculum 2004 (An Analysis Teaching in SMAN 3 Semarang Academic Year 2005/2006 by Using Grounded Theory Approach). A Final Project. State University of Semarang (2006).

[3] Limpscomb et al. Scaffolding. Online (2004).

[4] Seidel, J.V. Qualitative Data Analysis. Online (1998). 